\title{
Caloric Restriction as a Strategy to Improve Vascular Dysfunction in Metabolic Disorders
}

\author{
Concha F. García-Prieto ${ }^{1}$ and María S. Fernández-Alfonso ${ }^{2, *}$ \\ 1 The Rolf Luft Research Center for Diabetes and Endocrinology, Karolinska Institutet, Stockholm 17176, \\ Sweden; concepcion.fernandez.garcia-prieto@ki.se \\ 2 Instituto Pluridisciplinar and Facultad de Farmacia, Universidad Complutense, Madrid 28040, Spain \\ * Correspondence: marisolf@farm.ucm.es; Tel.: +34-913-943-254
}

Received: 13 March 2016; Accepted: 9 June 2016; Published: 15 June 2016

\begin{abstract}
Caloric restriction (CR) has proved to be the most effective and reproducible dietary intervention to increase healthy lifespan and aging. A reduction in cardiovascular disease (CVD) risk in obese subjects can be already achieved by a moderate and sustainable weight loss. Since pharmacological approaches for body weight reduction have, at present, a poor long-term efficacy, $\mathrm{CR}$ is of great interest in the prevention and/or reduction of CVD associated with obesity. Other dietary strategies changing specific macronutrients, such as altering carbohydrates, protein content or diet glycemic index have been also shown to decrease the progression of CVD in obese patients. In this review, we will focus on the positive effects and possible mechanisms of action of these strategies on vascular dysfunction.
\end{abstract}

Keywords: caloric restriction; dietary intervention; endothelial dysfunction; cardiovascular disease; obesity

\section{Introduction}

Obesity is a chronic disease due to an energetic imbalance in which caloric intake is higher than energetic expenditure. It is closely associated with insulin resistance and type 2 diabetes (T2D), leading to several manifestations of cardiovascular disease (CVD), such as hypertension, coronary artery disease, myocardial infarction, heart failure and stroke [1]. CVD is a major health problem worldwide accounting for $30 \%$ of all deaths and demands a global approach to prevention and early detection. In obese individuals, the earliest indication of vascular dysfunction preceding the development of prehypertension and hypertension is the impairment of endothelial function [2]. Therefore, endothelial function improvement should become a key approach to prevent and/or treat cardiovascular (CV) complications related to metabolic disorders.

The primary goal to reduce CVD risk in subjects who are overweight and obese is a moderate and sustainable weight loss. An improvement of multiple metabolic and hormonal factors implicated in the pathogenesis of CVD associated with metabolic disorders is already achieved by a weight loss of $5 \%-10 \%$ [3] that needs to be maintained over time. Since pharmacological approaches for body weight (BW) reduction have, at present, a poor long-term efficacy, other strategies such as caloric restriction (CR), exercise programs, or bariatric surgery are of great interest [3,4].

$\mathrm{CR}$ is defined as a state in which energy intake is reduced below usual ad libitum intake without malnutrition, independently of its duration. It is one of the most common and cost-effective interventions used to induce BW reduction and CV risk factor amelioration. Other dietary strategies changing specific macronutrients have also been shown to decrease progression of CVD. It is important to note that the induction of a negative energy balance is mandatory for achieving the metabolic benefits of weight loss since the sole reduction in fat mass alone by surgical procedures does not improve CV risk factors in obese patients $[5,6]$. Taking into consideration the complex and vast 
literature regarding dietary strategies, in this review, we will focus on the positive effects on vascular dysfunction, $\mathrm{CV}$ risk factors and CVD exerted by CR and macronutrients intake modification.

\section{CR Reduces CV Risk Factors}

Benefits on CV risk factors by reducing the daily caloric intake have been widely described in overweight and obese patients [7-19]. CR induces reductions in BW, waist perimeter, total fat, serum triglycerides (TG), or low-density lipoprotein (LDL)-cholesterol concentrations [12,14,20]. It is also associated with a reduction of circulating insulin levels together with an increase in insulin sensitivity $[12,14,18,20]$. The decrease in adiposity leads to reductions in leptin $[14,18]$, inflammatory cytokines, prostaglandins, and/or oxidative stress $[9,10,14,18]$, as well as to an increase in the anti-inflammatory Il-10 [14] and adiponectin (Figure 1) (see Section 4.4). In obese patients with or without associated hypertension, weight loss enhances flow-mediated vasodilation (FMD, which determines endothelial function in vivo) $[8,11]$, and induces a reduction in blood pressure (BP) $[7,20]$.

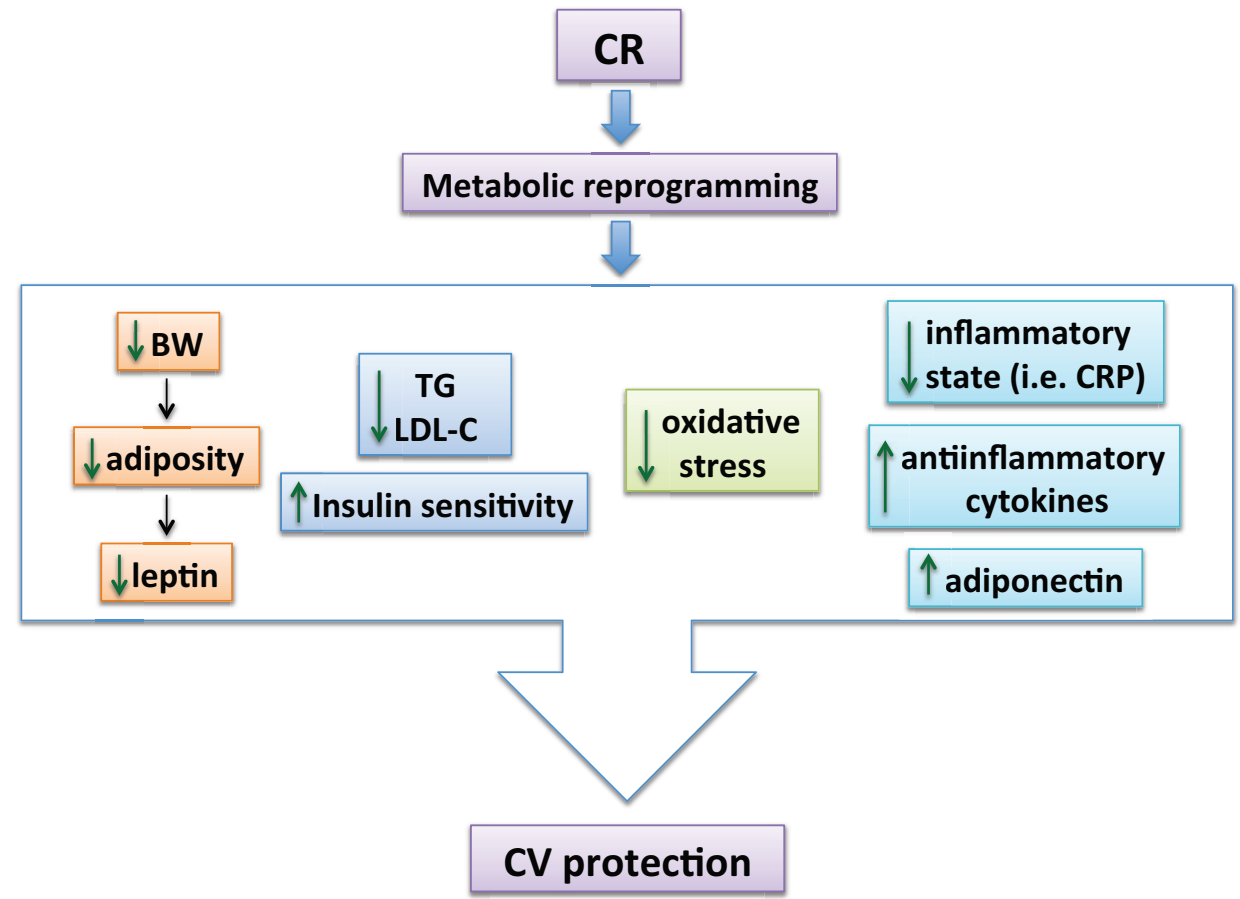

Figure 1. Main mechanisms by which CR exerts CV protection. Reducing the daily caloric intake induces a metabolic reprogramming in both healthy and obese individuals, subsequently leading to $\mathrm{CV}$ protection. This includes a reduction in BW and adiposity, thus lessening leptin levels. A decrease in TG and LDL-cholesterol levels together with less oxidative stress and inflammation and an increase in adiponectin levels are some of the main underlying mechanisms described (BW: body weight; CR: caloric restriction; CRP: high-sensitivity C-reactive protein; CV: cardiovascular; LDL-C: low-density lipoprotein -cholesterol; TG: triglycerides).

Interestingly, benefits of CR are not only observed in obese subjects. Long-term (3-15 years) $\mathrm{CR}$ in non-obese humans has a profound beneficial impact on CV risk factors, such as serum total cholesterol, LDL-cholesterol, high-density lipoprotein (HDL)-cholesterol, TG, and BP [20]. A decrease in the inflammatory state is reflected by the extremely low levels of high-sensitivity C-reactive protein (CRP) detected in these subjects [20]. Since CV risk factors increase with age, CR reveals as a promising strategy to prevent the development of CVD in both obese and non-obese individuals. However, it has to be noted that long-term interventions might not be equivalent to short-term interventions in 
the context of obesity and/or metabolic dysfunction, which may include increased resilience and/or improvements in indices of disease risk but are not associated with delayed aging (Figure 1).

\section{CR Protocols Differ in Their Starting Point, Severity, Duration and Number of Phases}

To assess and compare the effectiveness of CR protocols on CVD several aspects, such as CR severity, its duration, starting point and number of phases, need to be taken into account (Figure 2). A comparison of several approaches is shown in Table 1.

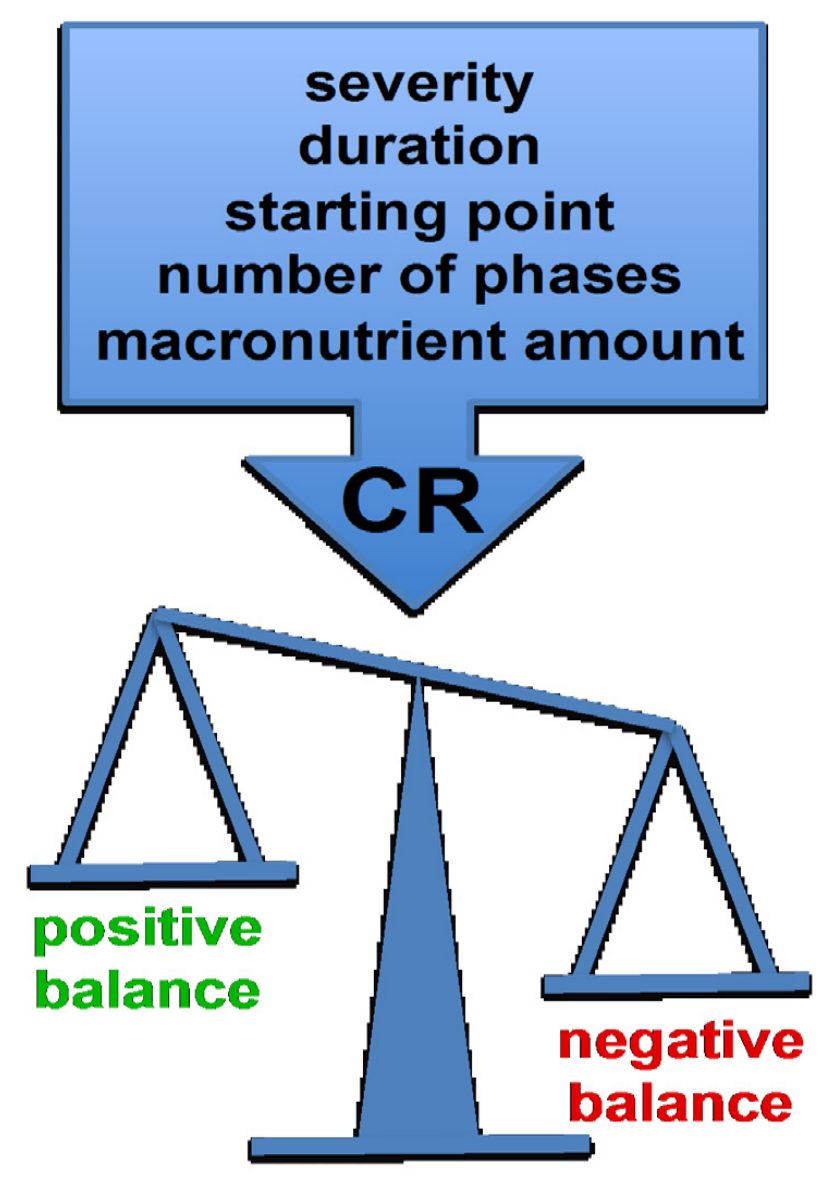

Figure 2. Critical aspects in a CR to achieve the desired effects. Although effects exerted by CR have been widely studied, there is no agreement in how a CR must be in order to prevent $\mathrm{CV}$ events. Numerous studies suggest that its severity, duration, starting point, number of phases and composition (i.e., macronutrient amount) are important aspects to take into account. Modifying all these characteristics in different ways can exert a positive or a negative balance, thus affecting CV risk factors (CR: caloric restriction; CV: cardiovascular).

There is no agreement on how severe a $\mathrm{CR}$ must be in order to confer benefits in different organs and systems. In general, the ad libitum (AL) caloric intake is reduced around $20 \%-40 \%$ exerting positive effects without deleterious consequences [21]. However, numerous protocols include an alternate-day fasting, in which caloric intake reduction will be intermittent [22,23]. Most of the CR protocols reduce very intensively the energetic consumption for a long time. Some examples include a daily $30 \%-40 \%$ reduction for 12 months or longer [24,25]. Others use comparable approaches but only for four or five weeks, obtaining similar effects [26]. This suggests that a CR does not need to be prolonged for a long time to be effective, with the advantage that short-term $\mathrm{CR}$ is easier to include in clinical practice. In this context, a genomic analysis revealed that the results obtained after CR during four weeks were similar to those from longer CR ( 28 weeks). In this study, the short-term CR revealed the $70 \%$ of 
the effects observed under the long-term CR on liver gene expression with age [27]. However, other authors report different findings in other tissues, such as in white adipose tissue [28], probably due to variations in responding to fasting cycles. Overall, we feel that most of the studies do not reflect a realistic intervention since they include really severe protocols.

Table 1. Comparison of several caloric restriction (CR) protocols in rodents and humans.

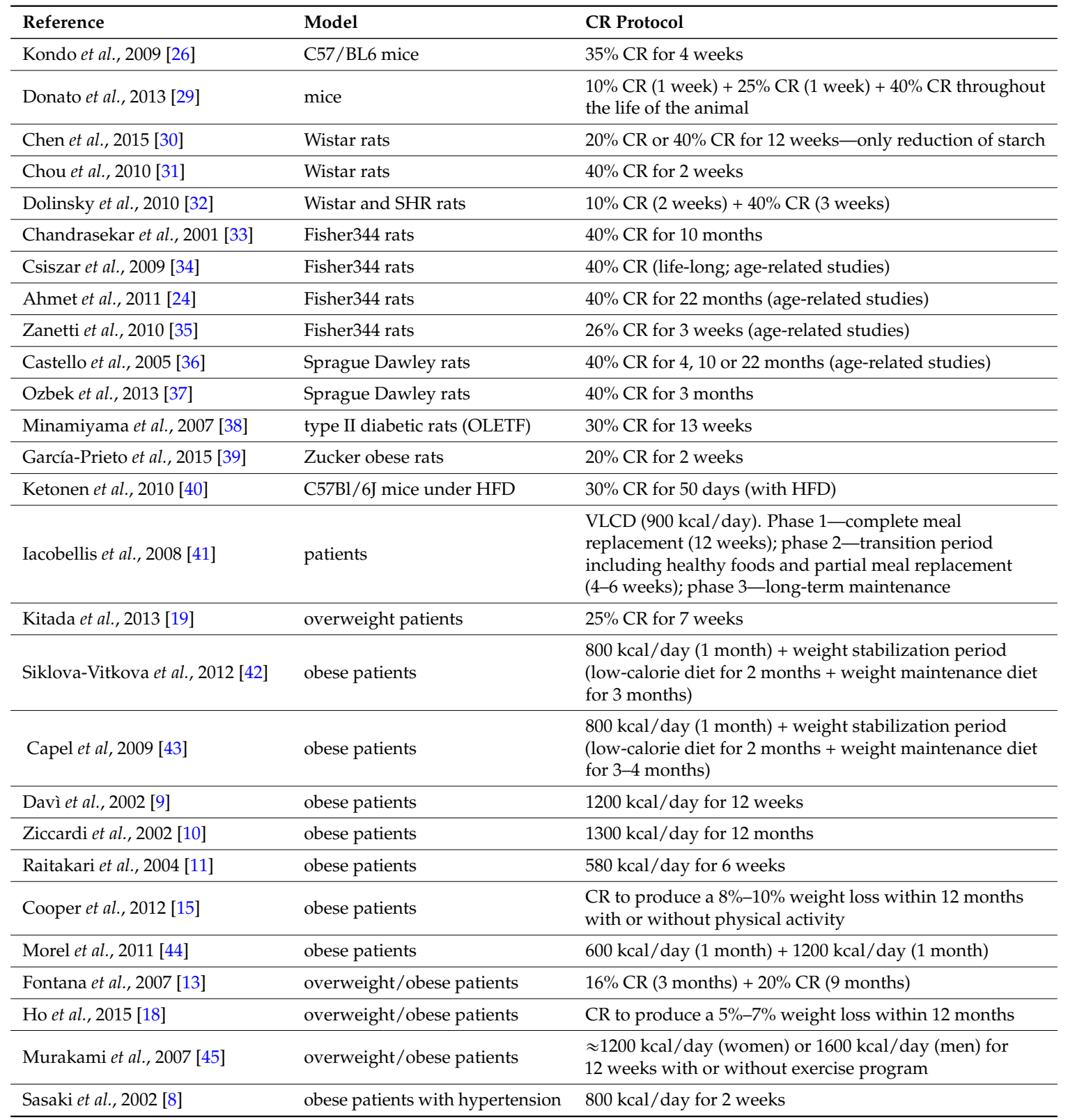

AL: ad libitum; CR: caloric restriction; HFD: high-fat diet; SHR: spontaneously hypertensive rats; VLCD: very low-calorie diet.

Initially, it was thought that benefits appeared only after long periods of CR [46]. Nevertheless some of the beneficial effects promoted by CR, such as plasmatic glucose levels decrease, show up within the first week of the diet [47]. Important protection of endothelial function occurs in vascular aging models even under CR protocols for less than three weeks [35,48]. Other vascular aged-related complications, such as aortic stiffening and artery wall hypertrophy, need longer dietary treatments to be prevented [29]. 
Regarding the starting point of a CR, its effects on lifespan are higher if it is initiated at the weaning [49-51]. A study in 10-week-old spontaneously hypertensive rats (SHR), with a moderate hypertension, showed that a $10 \%$ CR for two weeks followed by a $40 \%$ CR for three additional weeks avoided the increase in BP levels [32]. However, starting the same protocol at older ages, when BP values were higher $(>200 \mathrm{mmHg}$ ) could not reduce those values. This suggests that $\mathrm{CR}$ protocols might be more beneficial at early stages of vascular disease [32].

The different phases in which a CR can be subdivided play a substantial role in the achievements can be reached. In multiphase dietary interventions, the pattern of adipokine expression, secretion rate, and plasma levels is different with respect to the phase of the intervention, and to the cellular origin of the respective adipokine [42]. Adipocyte-derived adipokines (adiponectin, leptin, serum amyloid A, or haptoglobin) decrease (except for adiponectin), during the initial very low-calorie diet (VLCD), whereas they increase toward prediet levels during the weight stabilization phase. Similar results have been observed with low-calorie diets [52]. In contrast, expression and secretion rate of stromal-vascular fraction-derived adipokines (tumor necrosis factor $\alpha$ TNF- $\alpha$, interleukins IL-6, IL-10, IL-8, monocyte chemoattractant protein-1, and plasminogen activator inhibitor-1, PAI-1) increased or remained unchanged during the initial VLCD but decreased during the weight stabilization phase [42]. During the various phases of a dietary weight loss program, adipose tissue macrophages and adipocytes show distinct patterns of gene regulation and association with insulin sensitivity, the regulation of gene expression being dependent on the severity and duration of CR [43].

In conclusion, the optimal CR protocol for each specific situation remains to be determined and standardization will be necessary to allow comparison of the beneficial effects of different dietary approaches on CVD.

\section{Mechanisms by Which CR Exerts Vascular Protection in Metabolic Disorders}

The improvement of vascular dysfunction associated with metabolic disorders might be due to changes in endothelial function, in the arterial wall structure, or in the paracrine effects of perivascular adipose tissue (PVAT).

\subsection{Effects of CR on Endothelial Function}

$\mathrm{CR}$ leads to an improvement of endothelial function in arteries from several models of aged $[24,29,33,34,36,53]$ and obese rodents [38-40]. Underlying mechanisms include the increase of nitric oxide (NO) bioavailability $[29,31,35,48]$ due to the enhancement of endothelial nitric oxide synthase (eNOS) expression and/or activity [29,37,54], together with the suppression of vascular oxidative stress associated to superoxide anion $\left(\mathrm{O}_{2}{ }^{-}\right)$production $[29,31,34,38,40]$ and lipid peroxidation [38]. Vasoprotective effects of life-long CR both reduce the expression and activity of $\mathrm{NADPH}$ oxidase and $\mathrm{O}_{2}{ }^{-}$production, and enhance superoxide dismutase (SOD) activity [29].

Endothelial function improvement is also achieved by the reduction of inflammatory mediators, such as CRP, which is a moderately good predictor of acute vascular events related to obesity [55], IL-6 and TNF- $\alpha$ in mice [55], as well as decreases in nuclear factor NF- $k B$ activity $[33,34]$.

A key event associated with the improvement of endothelial function under CR is the activation of the AMPK-PI3K-Akt-eNOS signaling pathway. A dysregulation of this pathway in over-nutrition and obesity contributes to the development of endothelial dysfunction (for review, see [56]) in both diet-induced [57] and genetic models of obesity, such as Zucker $f a / f a$ obese rats [58], Zucker diabetic fatty rats [59] or Otsuka Long Evans Tokushima Fatty rats [60]. CR triggers endothelial AMPK activation leading to (i) normalization of endothelial function and systolic BP reduction in Zucker obese rats [39]; (ii) an improvement of vascular compliance and BP reduction in hypertensive rats [32]; or (iii) revascularization in response to ischemia [26]. Moreover, activation of AMPK by CR reduces lipotoxicity associated with high-fat diets (HFD), insulin resistance, and obesity by decreasing the excessive exposure of the endothelium to free fatty-acids (FFAs) [61,62], thus exerting a protective effect on endothelial cells $[61,62]$. Obese patients subjected to CR that reported systolic BP reduction, as 
well as FFA and inflammatory marker level decrease, showed an increase of AMPK phosphorylation in peripheral blood mononuclear cells [19]. The fact that these changes are observed even with a moderate reduction in BW supports the predominant role of the negative energy balance to achieve CV benefits of CR.

Activation of the cellular sensing protein sirtuin-1 (SIRT1) is another mechanism proposed as key mediator of vascular benefits of CR [29,34]. Arterial aging is associated with changes in expression and/or activity of SIRT1 and mammalian target of rapamycin (mTOR), which are ameliorated by life-long CR. In the same line, serum obtained from CR patients activates SIRT1 in human cells in vitro [63]. There are, however, very few studies assessing the vascular role of SIRT1 activation by CR in obesity, and further research needs to be performed in this line.

\subsection{Effects of CR on Arterial Wall Structure and Remodeling}

Subclinical organ damage, such as vascular remodeling, precedes the occurrence of CV events in individuals with obesity and hypertension [64]. Life-long CR significantly reduces large elastic artery wall hypertrophy and prevents aortic stiffening in mice [29] due to a suppression of collagen production [29] and elastin fiber degradation [53]. Increases in elasticity after CR have also been described in arteries from young, but not from aged SHR [32]. This suggests that reversal of early changes in the arterial wall structure, at a time when vascular remodeling is emerging and still reversible, is essential for the prevention of vascular dysfunction.

Mechanisms underlying CR-induced changes in vascular remodeling have been mainly analyzed in models of aging. CR introduced early in life protects against aortic fibrosclerosis by decreasing oxidative damage and consequently reducing the levels of transforming growth factor beta-1 (TGF $\beta 1$ ). This change very likely occurs through a downregulation of the mitogen-activated protein kinases (MAPK), c-Jun N-terminal kinase (JNK) and activator protein-1 (AP-1) signaling pathways [36]. Whether the same mechanisms underlie the effects of $C R$ on metabolic arterial wall remodeling remains to be further analyzed.

Both intervention and cross-sectional studies in humans demonstrate that short-term CR and reduced BW are associated with lower BP and carotid wall thickness [15,16,20,65]. A weight loss of around $8 \%$ results in a mean decrease of $0.07 \mathrm{~mm}$ in carotid artery diameter, whereas individuals who achieved at least a 5\% weight loss showed a significant reduction in mean carotid intima:media thickness [15]. A meta-analysis of 43 studies on moderate weight loss (around 11\%) due to CR, with or without exercise, demonstrates an improvement of some arterial compliance and stiffness parameters, such as cardio-ankle vascular and $\beta$-stiffness index, arterial compliance and distensibility, distal oscillatory compliance, proximal capacitive compliance, systemic arterial compliance or reflection time. However, other parameters, such as augmentation index, strain, augmentation pressure and pulse pressure were not significantly improved with weight loss [66]. All of these results demonstrate that an intensive dietary intervention at a time when vascular remodeling has only been initiated and is not irreversibly established might significantly reverse some of the key adverse vascular structural changes associated with excess weight in severely obese adults.

\subsection{Effects of CR on PVAT Dysfunction in Obesity}

Perivascular adipose tissue (PVAT) is the adipose tissue surrounding most blood vessels, except cerebral vessels. It might be white or brown adipose tissue and produces a number of vasoactive factors, adipokines and cytokines. A large body of evidence supports the paracrine influence of PVAT for the maintenance of vascular resistance under physiological and pathophysiological conditions [67]. PVAT releases a number of adipokines, inflammatory cytokines, and other vasoactive factors, which are variable in quantity and pattern depending on the PVAT amount [67]. In fact, obesity triggers an increase in PVAT throughout the vasculature [68,69], accompanied by an unbalance in favor of vasoconstrictor and pro-inflammatory substances, which leads to endothelial dysfunction and vascular damage [70-72]. Long-term HFD in mice leads to PVAT dysfunction, characterized by an increase in 
NADPH oxidase activity and $\mathrm{O}_{2}{ }^{-}$release, as well as by a reduction in extracellular SOD expression, total SOD activity, eNOS levels, and NO availability [70]. Similarly, PVAT of New Zealand obese mice show increased $\mathrm{O}_{2}-$ levels formation and decreased SOD expression, leading to an impaired hydrogen peroxide $\left(\mathrm{H}_{2} \mathrm{O}_{2}\right)$ production, which contributes to vascular dysfunction reducing the anti-contractile effects of PVAT [73]. In Ossabaw obese swine $\mathrm{H}_{2} \mathrm{O}_{2}$-mediated vasodilatation was markedly attenuated by the presence of coronary PVAT [74]. Ma et al. [72] showed that PVAT induces endothelial dysfunction by dysregulation of the AMPK/mTOR pathway in the aorta of diet-induced obese rats, characterized by a downregulation of AMPK-eNOS pathway and a concurrent upregulation of mTOR. Moreover, obese periaortic PVAT high FFA levels could attenuate the anti-contractile properties of PVAT by a TNF- $\alpha$-dependent [75].

An interesting issue, which deserves future investigation, is the impact of the diet composition on oxidative stress in PVAT. A fructose-rich diet, which decreases polyunsaturated FAs and increases saturated and monounsaturated FAs in PVAT impairs vascular function by a decrease in antioxidant enzymes and a reduction in glutathione content [76]. Altogether, these results indicate that obesity and the diet composition induce a switch in PVAT to a more pro-inflammatory, pro-oxidant and vasoconstrictor phenotype.

Since the beneficial or deleterious paracrine influence of PVAT is directly dependent on its amount $[77,78]$, a key question is whether the proportion of adipose tissue loss induced by CR is uniform (overall adiposity) or predominant in specific adipose depots (i.e., PVAT). Significant reduction in the thickness of epicardial fat (surrounding coronary arteries) has been described both in severely obese patients who underwent substantial weight loss after bariatric surgery [79], as well as after a short-term VLCD program [41]. Interestingly, the decrease of epicardial fat is substantially higher than changes in overall BW loss body mass index and waist circumference, and correlates with the improvement in both left ventricular mass and diastolic function. Interestingly, bariatric surgery also reverses the obesity-induced damage to PVAT anticontractile function by reducing adipocyte hypertrophy, PVAT inflammation and increasing both PVAT-derived NO and adiponectin availability [80]. We believe that these studies open a new approach for the management of vascular damage and CV risk associated with PVAT dysfunction in metabolic related disorders.

\subsection{Effects of CR on Vascular Actions of Leptin and Adiponectin}

Obesity is associated with hyperleptinemia and hypoadiponectinemia, both playing a key role in the pathogenesis of endothelial dysfunction [81]. Chronic hyperleptinemia has been linked to endothelial dysfunction and damage [82-84] stimulating the increase in NADPH oxidase activity and $\mathrm{O}_{2}{ }^{-}$production in the vascular wall, as well as promoting glutathione peroxidase activation to remove excessive $\mathrm{H}_{2} \mathrm{O}_{2}$ production. On the other hand, hypoadiponectinemia is closely associated with endothelial dysfunction in humans and adiponectin knock-out mice show a decrease in eNOS phosphorilation levels.

Different $\mathrm{CR}$ protocols in rats, markedly changes the adipokine production pattern leading to an increase in circulating levels of adiponectin, whereas leptin levels profoundly decrease in adipose tissue $[85,86]$.

A role for adipokine levels in PVAT and their paracrine influence on the vascular wall might not be discarded. $\mathrm{Ob} / \mathrm{ob}$ mice lacking leptin do not exhibit $\mathrm{NO}$ production in perivascular adipocytes. Interestingly, this is restored in PVAT after two-week subcutaneous leptin infusion, suggesting that NO release in PVAT seems to be mediated by leptin [87]. Hypoadiponectinemia in patients with T2D stimulates vascular NADPH oxidase expression, which is counterbalanced by upregulation of adiponectin expression in PVAT aimed at suppressing in a paracrine manner NADPH oxidase activity via a PI3K/Akt-mediated deactivation of Rac1 and the downregulation of $\mathrm{p}^{22^{\mathrm{phox}}}$ gene expression [88]. These studies again stress the concept that PVAT-vessel interaction is a promising therapeutic target for the prevention of vascular complications of metabolic disorders. The effect of CR and dietary approaches on this interaction deserves future investigation. 


\section{Dietary Strategies Based on Macronutrients Modification}

Not only the amount but also the quality of the nutrient intake contributes to benefits on vascular function [89-91]. However, any dietary change can be universally applied as positive at the CV level since their beneficial effects are different depending on the metabolic state of the individual. Although dietary interventions need to be personalized on the basis of patient requirements, some of the most widely approaches used in clinical practice regarding macronutrients content on the diet and its effects at vascular level are described in Sections 5.1 to 5.3 below.

\subsection{Low-Carbohydrate Diets}

In both overweight and obese patients, carbohydrate restricted diets are more effective than low-fat diets in terms of atherogenic dyslipemia and other metabolic syndrome characteristics such as inflammation, oxidative stress and CV risk markers (i.e., apolipoproteins A- 1 and B, LDL particle distribution, and FMD) [92-95]. Peripheral small artery vascular function is improved with low carbohydrate diets when there is a decrease in BW [96,97]. However, some authors report that the degree of weight loss in obese patients is not correlated to changes in BP, endothelial function and inflammatory markers [98]. Restricting dietary carbohydrate positively impacts lipid homeostasis and inflammatory markers (i.e., TNF- $\alpha$, IL-6, PAI-1) even when the saturated fat intake is higher due to the isocaloric replacement of carbohydrates [92-95]. Dysregulation of PAI-1 is involved in enhanced inflammation, vascular damage and subsequent thrombogenicity [99]. Thus, studies with different dietary interventions aim to establish PAI-1 as a possible therapeutic target for controlling CVD in obese patients [44,45]. Moreover, beneficial effects of carbohydrate restriction in combination with pharmacological treatments, i.e., statins, have been described [98]. A decrease in approximately $400 \mathrm{kcal} /$ day for six weeks (with carbohydrates representing the $11 \%$ of the daily intake) reduced $\mathrm{CV}$ risk markers such as serum TG, soluble E-selectin and intracellular adhesion molecule-1. Both systolic and diastolic BP decreased together with an increase in reactive hyperemia, indicating a better resistance vessel endothelial function, probably in a prostaglandins-mediated way and independent of NO increase [98,100].

However, there is no consensus regarding how much the carbohydrate amount of the diet must be reduced to be beneficial. A recent study comparing the effects of two low-carbohydrate diets for 12 weeks in rats $(80 \%$ energy intake with $34 \%$ carbohydrate reduction $v$ s. $60 \%$ energy intake with $68 \%$ carbohydrate reduction of the control diet) demonstrated that decreasing carbohydrate intake to a large extent even with a lower caloric intake has detrimental effects on lipid balance due to an increase in LDL and total cholesterol levels [30]. Indeed, dietary patterns characterized by a low amount of carbohydrate but reciprocally higher content in fat and protein are related to a poorer vascular reactivity in overweight and obese patients [97] and in patients with T2D and increased vascular risk [101]. This emphasizes the necessity of studying the impact of macronutrient composition and nature on CVD (Figure 3).

\subsection{Higher Protein Content: Does It Make the Difference?}

Diets low in carbohydrates have been proven to reduce BW in both overweight and obese patients $[91,96,97,102]$ and to maintain weight when associated with a moderate increase in protein amount [103]. Low-fat/high-protein diets are more effective for long-term maintenance or further improvement of vascular function [104,105]. Thus, energy-restricted diets are generally compensated by protein content, usually with meal replacements [101,105]. Obese T2D subjects receiving either a meal replacement-based low-calorie diet (approximately $1000 \mathrm{kcal} /$ day) or a low-fat, high-protein, reduced-carbohydrate diet (HP, intake decrease about $600 \mathrm{kcal} /$ day) for eight weeks and either switching to or continuing with the HP diet for 44 additional weeks showed similar positive impacts on endothelial function and inflammatory markers [105]. Both diets reduced blood glucose, TG and LDL-cholesterol and improved endothelial function by lessening soluble E-selectin and increasing 
FMD. However, only the HP diet decreased CRP and IL-6 levels, markers of inflammation related to vascular homeostasis. Controlled trials in which obese patients were assigned to two periods of a four-week hypocaloric diet (either high in proteins or a conventional one, $1200 \mathrm{kcal} /$ day) [106] showed similar results in some metabolic risk markers after both diets. Interestingly, diets high in protein were associated with improvement in some cardiometabolic risk factors such as PAI-1, vascular endothelial growth factor, fasting plasma glucose and CRP despite the fact of its higher fat content. However, only the conventional hypocaloric diet decreased systolic BP, highlighting the importance of every macronutrient maintaining vascular homeostasis in obese patients [106]. Since high CRP precedes atheromatic events [107], lessening its levels could pave the way to better prevent CV disease. Some clinical trials (i.e., the OmniHeart study) support the idea that a partial replacement of carbohydrates with either protein or monounsaturated fat has additional beneficial effects on the basis of a healthy diet at a vascular level independent of BW loss in both non-obese and obese patients with prehypertension or stage 1 hypertension [108]. Without reducing caloric intake (2100 kcal/day), these patients further reduced systolic and diastolic BP and decreased estimated risk of suffering coronary heart disease with both diets rich in protein or rich in unsaturated fat [108].

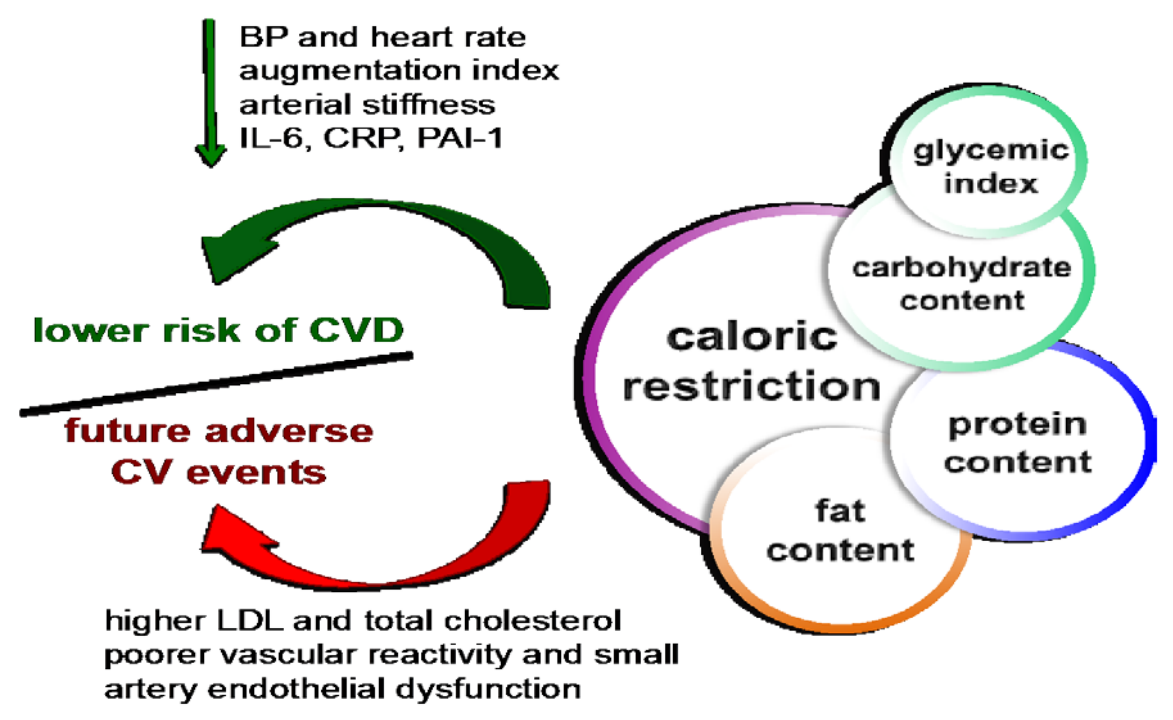

Figure 3. $\mathrm{CV}$ outcome of $\mathrm{CR}$ depends on macronutrient composition of the diet. Both the amount and the quality of each macronutrient of the diet are important in order to achieve positive effects at CV level. A proper balance in macronutrient amount is key to avoid future adverse CV events (BP: blood pressure; CR: caloric restriction; CRP: high-sensitivity C-reactive protein; CV: cardiovascular; CVD: cardiovascular disease; IL-6: interleukin 6; LDL: low-density lipoprotein; PAI-1: plasminogen activator inhibitor-1).

Besides the positive effects that a protein supplementation can exert, replacing carbohydrates with higher amounts of protein and fat lead to a low small artery reactive hyperaemia index, a marker of small artery endothelial function [101], which correlates with endothelial dysfunction [109], thus predicting future adverse CV events [110]. Hence, balancing the amount of each macronutrient of the diet might be of importance for achieving positive effects at the CV level (Figure 3).

\subsection{Diet Glycemic Index Variation}

Both the carbohydrate and fat content of a diet influences the occurrence of diabetes and CVD [102,111]. Although diets restricting carbohydrate consumption are a well-known strategy for weight loss with the subsequent improvement of metabolic-related complications in overweight and obese patients [102], recent studies show that following these diets for a long time does not always protect from CVD $[101,112,113]$. In this context, changing carbohydrate quality rather than 
quantity has emerged as a better approach to dealing with CV risk factors. Glycemic index (GI) is the quantification of the blood glucose response to a carbohydrate compared to a carbohydrate reference [114]. That is, foods with similar carbohydrate content can behave differently in terms of raising blood glucose. Thus, varying GI might be useful in the management of these diseases (Figure 3). The effects on metabolism exerted by different GI diets are diverse $[89,91,115]$. Control trials in which obese patients at increased CV risk were subjected to hypocaloric diets with different GI for three months showed a decrease in BW, plasma glucose, total cholesterol, LDL-cholesterol, TG, systolic BP and heart rate independent of the GI of the diet [91]. Interestingly, FMD was influenced, being higher after following the low GI diet [91], a fact observed in studies assessing the acute effects of different GI diets [89]. In this context, the EVIDENT study (2010, Spain) aims to establish an association between GI and vascular homeostasis by assessing arterial stiffness (via pulse wave velocity measurement) and augmentation index (vascular aging related to endothelial dysfunction) [116]. Their latest results show that an increase in GI correlates with an enhancement of augmentation index, thus increasing the risk of suffering a CVD [116]. Low GI diets can reduce oxidative stress [117] and inflammation [90], factors widely associated with endothelial dysfunction. In this context, low GI hypocaloric diets have been shown to decrease CRP blood levels in overweight patients [90]. However, some clinical trials claim that GI is not related to an improvement in CV risk factors on the basis of a healthy diet [118]. In this controlled feeding study, the effects of four different interventions on carbohydrate content from a healthy diet without losing weight were analyzed. No differences were observed between high and low GI diets regarding insulin sensitivity, lipid homeostasis and systolic BP [118]. All of these diverse results between studies may be due to changes in content of total carbohydrates and fibers, no concomitant weight loss and duration of the dietary treatment, although long-term studies with BW decrease conclude in a similar way $[90,119]$.

\section{Conclusions}

All the described dietary modifications are effective by mitigating CV risk factors in obesity. However, despite all the efforts made to establish CR or a balanced diet as the main strategies to either prevent or treat $\mathrm{CV}$ complications related to metabolic disorders, there is no fully effective formula, and factors such as severity, duration, starting point, number of phases and composition need to be taken into account. It is important to note that an intensive dietary intervention at a time when vascular dysfunction has only been initiated and is not irreversibly established might significantly reverse some of the key adverse vascular changes associated with obesity.

On the other hand, many mechanisms underlying CR-induced changes in vascular dysfunction have been mainly analyzed in models of aging (i.e., vascular remodeling). Whether the same mechanisms underlie the effects of $C R$ on obesity related vascular dysfunction remains to be further analyzed. In addition, most of these regimens have the ability to attenuate some, but not all, of the components involved in this complicated multifactorial condition. Therefore, further research is needed to understand in depth the mechanisms involved in the positive effects of $C R$ and macronutrient intake modification on vascular dysfunction associated with being overweight and obese.

Moreover, we need to define specific biomarkers to (i) assess and/or predict the effect CR on CV risk and (ii) design an optimal and more personalized dietary regime, taking into account individual differences in age, metabolic function and $\mathrm{CV}$ risk factors.

Acknowledgments: This work was supported by SAF2011-25303, GR921641-Santander, Fundación Mutua Madrileña and Fundación Eugenio Rodríguez Pascual.

Author Contributions: Both authors generated the concept of the review, and wrote and approved the text.

Conflicts of Interest: The authors declare no conflict of interest. 


\section{Abbreviations}

The following abbreviations are used in this manuscript:

\begin{tabular}{|c|c|}
\hline Akt & protein kinase B \\
\hline $\mathrm{AL}$ & ad libitum \\
\hline AMPK & adenosine monophosphate-activated protein kinase \\
\hline AP-1 & activator protein-1 \\
\hline $\mathrm{BP}$ & blood pressure \\
\hline BW & body weight \\
\hline CR & caloric restriction \\
\hline CRP & high-sensitivity C-reactive protein \\
\hline $\mathrm{CV}$ & cardiovascular \\
\hline CVD & cardiovascular disease \\
\hline eNOS & endothelial nitric oxide synthase \\
\hline FA & fatty acid \\
\hline FFAs & free fatty-acids \\
\hline FMD & flow-mediated dilation \\
\hline GI & glycemic index \\
\hline $\mathrm{H}_{2} \mathrm{O}_{2}$ & hydrogen peroxide \\
\hline HDL & high-density lipoprotein \\
\hline HFD & high-fat diet \\
\hline $\mathrm{HP}$ & low-fat, high-protein, reduced-carbohydrate \\
\hline IL & interleukin \\
\hline JNK & c-Jun N-terminal kinase \\
\hline LDL & low-density lipoprotein \\
\hline MAPK & mitogen-activated protein kinases \\
\hline MCP-1 & monocyte chemoattractant protein- 1 \\
\hline mTOR & mammalian target of rapamycin \\
\hline$N F-k B$ & nuclear factor $\mathrm{kB}$ \\
\hline $\mathrm{NO}$ & nitric oxide \\
\hline $\mathrm{O}_{2}^{-}$ & superoxide anion \\
\hline PAI-1 & plasminogen activator inhibitor-1 \\
\hline PI3K & phosphoinositide 3-kinase \\
\hline PVAT & perivascular adipose tissue \\
\hline SHR & spontaneously hypertensive rats \\
\hline SIRT1 & sirtuin-1 \\
\hline SOD & superoxide dismutase \\
\hline $\mathrm{T} 2 \mathrm{D}$ & type 2 diabetes \\
\hline TG & triglycerides \\
\hline TGF $\beta 1$ & transforming growth factor beta- 1 \\
\hline TNF- $\alpha$ & tumor necrosis factor $\alpha$ \\
\hline VLCD & very low-calorie diet \\
\hline
\end{tabular}

\section{References}

1. Galassi, A.; Reynolds, K.; He, J. Metabolic syndrome and risk of cardiovascular disease: A meta-analysis. Am. J. Med. 2006, 119, 812-819. [CrossRef] [PubMed]

2. DeMarco, V.G.; Aroor, A.R.; Sowers, J.R. The pathophysiology of hypertension in patients with obesity. Nat. Rev. Endocrinol. 2014, 10, 364-376. [CrossRef] [PubMed]

3. Wing, R.R.; Lang, W.; Wadden, T.A.; Safford, M.; Knowler, W.C.; Bertoni, A.G.; Hill, J.O.; Brancati, F.L.; Peters, A.; Wagenknecht, L.; et al. Benefits of modest weight loss in improving cardiovascular risk factors in overweight and obese individuals with type 2 diabetes. Diabetes Care 2011, 34, 1481-1486. [CrossRef] [PubMed]

4. Sjöström, L.; Lindroos, A.K.; Peltonen, M.; Torgerson, J.; Bouchard, C.; Carlsson, B.; Dahlgren, S.; Larsson, B.; Narbro, K.; Sjöström, C.D.; et al. Lifestyle, diabetes, and cardiovascular risk factors 10 years after bariatric surgery. N. Engl. J. Med. 2004, 351, 2683-2693. [CrossRef] [PubMed]

5. Klein, S.; Fontana, L.; Young, V.L.; Coggan, A.R.; Kilo, C.; Patterson, B.W.; Mohammed, B.S. Absence of an effect of liposuction on insulin action and risk factors for coronary heart disease. N. Engl. J. Med. 2004, 350, 2549-2557. [CrossRef] [PubMed] 
6. Fabbrini, E.; Tamboli, R.A.; Magkos, F.; Marks-Shulman, P.A.; Eckhauser, A.W.; Richards, W.O.; Klein, S.; Abumrad, N.N. Surgical removal of omental fat does not improve insulin sensitivity and cardiovascular risk factors in obese adults. Gastroenterology 2010, 139, 448-455. [CrossRef] [PubMed]

7. Stevens, V.J.; Obarzanek, E.; Cook, N.R.; Lee, I.M.; Appel, L.J.; Smith West, D.; Milas, N.C.; Mattfeldt-Beman, M.; Belden, L.; Bragg, C.; et al. Long-term weight loss and changes in blood pressure: Results of the trials of hypertension prevention, phase II. Ann. Intern. Med. 2001, 134, 1-11. [CrossRef] [PubMed]

8. Sasaki, S.; Higashi, Y.; Nakagawa, K.; Kimura, M.; Noma, K.; Hara, K.; Matsuura, H.; Goto, C.; Oshima, T.; Chayama, K. A low-calorie diet improves endothelium-dependent vasodilation in obese patients with essential hypertension. Am. J. Hypertens. 2002, 15, 302-309. [CrossRef]

9. Davì, G.; Guagnano, M.T.; Ciabattoni, G.; Basili, S.; Falco, A.; Marinopiccoli, M.; Nutini, M.; Sensi, S.; Patrono, C. Platelet activation in obese women: Role of inflammation and oxidant stress. JAMA 2002, 288, 2008-2014. [CrossRef] [PubMed]

10. Ziccardi, P.; Nappo, F.; Giugliano, G.; Esposito, K.; Marfella, R.; Cioffi, M.; D’Andrea, F.; Molinari, A.M.; Giugliano, D. Reduction of inflammatory cytokine concentrations and improvement of endothelial functions in obese women after weight loss over one year. Circulation 2002, 105, 804-809. [CrossRef] [PubMed]

11. Raitakari, M.; Ilvonen, T.; Ahotupa, M.; Lehtimäki, T.; Harmoinen, A.; Suominen, P.; Elo, J.; Hartiala, J.; Raitakari, O.T. Weight reduction with very-low-caloric diet and endothelial function in overweight adults: Role of plasma glucose. Arterioscler. Thromb. Vasc. Biol. 2004, 24, 124-128. [CrossRef] [PubMed]

12. Pereira, M.A.; Swain, J.; Goldfine, A.B.; Rifai, N.; Ludwig, D.S. Effects of a low-glycemic load diet on resting energy expenditure and heart disease risk factors during weight loss. JAMA 2004, 292, 2482-2490. [CrossRef] [PubMed]

13. Fontana, L.; Villareal, D.T.; Weiss, E.P.; Racette, S.B.; Steger-May, K.; Klein, S.; Holloszy, J.O.; Washington University School of Medicine CALERIE Group. Calorie restriction or exercise: Effects on coronary heart disease risk factors. A randomized, controlled trial. Am. J. Physiol. Endocrinol. Metab. 2007, 293, E197-E202. [CrossRef] [PubMed]

14. Jung, S.H.; Park, H.S.; Kim, K.S.; Choi, W.H.; Ahn, C.W.; Kim, B.T.; Kim, S.M.; Lee, S.Y.; Ahn, S.M.; Kim, Y.K.; et al. Effect of weight loss on some serum cytokines in human obesity: Increase in IL-10 after weight loss. J. Nutr. Biochem. 2008, 19, 371-375. [CrossRef] [PubMed]

15. Cooper, J.N.; Columbus, M.L.; Shields, K.J.; Asubonteng, J.; Meyer, M.L.; Sutton-Tyrrell, K.; Goodpaster, B.H.; DeLany, J.P.; Jakicic, J.M.; Barinas-Mitchell, E. Effects of an intensive behavioral weight loss intervention consisting of caloric restriction with or without physical activity on common carotid artery remodeling in severely obese adults. Metabolism 2012, 61, 1589-1597. [CrossRef] [PubMed]

16. Samaras, K.; Viardot, A.; Lee, P.N.; Jenkins, A.; Botelho, N.K.; Bakopanos, A.; Lord, R.V.; Hayward, C.S. Reduced arterial stiffness after weight loss in obese type 2 diabetes and impaired glucose tolerance: The role of immune cell activation and insulin resistance. Diabetes Vasc. Dis. Res. 2013, 10, 40-48. [CrossRef] [PubMed]

17. Soare, A.; Weiss, E.P.; Pozzilli, P. Benefits of caloric restriction for cardiometabolic health, including type 2 diabetes mellitus risk. Diabetes Metab. Res. Rev. 2014, 30, 41-47. [CrossRef] [PubMed]

18. Ho, T.P.; Zhao, X.; Courville, A.B.; Linderman, J.D.; Smith, S.; Sebring, N.; Della Valle, D.M.; Fitzpatrick, B.; Simchowitz, L.; Celi, F.S. Effects of a 12-month moderate weight loss intervention on insulin sensitivity and inflammation status in nondiabetic overweight and obese subjects. Horm. Metab. Res. 2015, 47, 289-296. [CrossRef] [PubMed]

19. Kitada, M.; Kume, S.; Takeda-Watanabe, A.; Tsuda, S.; Kanasaki, K.; Koya, D. Calorie restriction in overweight males ameliorates obesity-related metabolic alterations and cellular adaptations through anti-aging effects, possibly including AMPK and SIRT1 activation. Biochim. Biophys. Acta 2013, 1830, 4820-4827. [CrossRef] [PubMed]

20. Fontana, L.; Meyer, T.E.; Klein, S.; Holloszy, J.O. Long-term calorie restriction is highly effective in reducing the risk for atherosclerosis in humans. Proc. Natl. Acad. Sci. USA 2004, 101, 6659-6663. [CrossRef] [PubMed]

21. Piper, M.D.; Bartke, A. Diet and aging. Cell Metab. 2008, 8, 99-104. [CrossRef] [PubMed]

22. Varady, K.A.; Hellerstein, M.K. Alternate-day fasting and chronic disease prevention: A review of human and animal trials. Am. J. Clin. Nutr. 2007, 86, 7-13. [PubMed] 
23. Heilbronn, L.K.; Smith, S.R.; Martin, C.K.; Anton, S.D.; Ravussin, E. Alternate-day fasting in nonobese subjects: Effects on body weight, body composition, and energy metabolism. Am. J. Clin. Nutr. 2005, 81, 69-73. [PubMed]

24. Ahmet, I.; Tae, H.J.; de Cabo, R.; Lakatta, E.G.; Talan, M.I. Effects of calorie restriction on cardioprotection and cardiovascular health. J. Mol. Cell. Cardiol. 2011, 51, 263-271. [CrossRef] [PubMed]

25. Colman, R.J.; Anderson, R.M.; Johnson, S.C.; Kastman, E.K.; Kosmatka, K.J.; Beasley, T.M.; Allison, D.B.; Cruzen, C.; Simmons, H.A.; Kemnitz, J.W.; et al. Caloric restriction delays disease onset and mortality in rhesus monkeys. Science 2009, 325, 201-204. [CrossRef] [PubMed]

26. Kondo, M.; Shibata, R.; Miura, R.; Shimano, M.; Kondo, K.; Li, P.; Ohashi, T.; Kihara, S.; Maeda, N.; Walsh, K.; et al. Caloric restriction stimulates revascularization in response to ischemia via adiponectin-mediated activation of endothelial nitric-oxide synthase. J. Biol. Chem. 2009, 284, 1718-1724. [CrossRef] [PubMed]

27. Cao, S.X.; Dhahbi, J.M.; Mote, P.L.; Spindler, S.R. Genomic profiling of short- and long-term caloric restriction effects in the liver of aging mice. Proc. Natl. Acad. Sci. USA 2001, 98, 10630-10635. [CrossRef] [PubMed]

28. Higami, Y.; Barger, J.L.; Page, G.P.; Allison, D.B.; Smith, S.R.; Prolla, T.A.; Weindruch, R. Energy restriction lowers the expression of genes linked to inflammation, the cytoskeleton, the extracellular matrix, and angiogenesis in mouse adipose tissue. J. Nutr. 2006, 136, 343-352. [PubMed]

29. Donato, A.J.; Walker, A.E.; Magerko, K.A.; Bramwell, R.C.; Black, A.D.; Henson, G.D.; Lawson, B.R.; Lesniewski, L.A.; Seals, D.R. Life-long caloric restriction reduces oxidative stress and preserves nitric oxide bioavailability and function in arteries of old mice. Aging Cell 2013, 12, 772-783. [CrossRef] [PubMed]

30. Chen, J.H.; Ouyang, C.; Ding, Q.; Song, J.; Cao, W.; Mao, L. A moderate low-carbohydrate low-calorie diet improves lipid profile, insulin sensitivity and adiponectin expression in rats. Nutrients 2015, 7, 4724-4738. [CrossRef] [PubMed]

31. Chou, S.H.; Lee, Y.C.; Huang, C.F.; Wang, Y.R.; Yu, H.P.; Lau, Y.T. Gender-specific effects of caloric restriction on the balance of vascular nitric oxide and superoxide radical. Cardiovasc. Res. 2010, 87, 751-759. [CrossRef] [PubMed]

32. Dolinsky, V.W.; Morton, J.S.; Oka, T.; Robillard-Frayne, I.; Bagdan, M.; Lopaschuk, G.D.; Des Rosiers, C.; Walsh, K.; Davidge, S.T.; Dyck, J.R. Calorie restriction prevents hypertension and cardiac hypertrophy in the spontaneously hypertensive rat. Hypertension 2010, 56, 412-421. [CrossRef] [PubMed]

33. Chandrasekar, B.; Nelson, J.F.; Colston, J.T.; Freeman, G.L. Calorie restriction attenuates inflammatory responses to myocardial ischemia-reperfusion injury. Am. J. Physiol. Heart Circ. Physiol. 2001, 280, H2094-H2102. [PubMed]

34. Csiszar, A.; Labinskyy, N.; Jimenez, R.; Pinto, J.T.; Ballabh, P.; Losonczy, G.; Pearson, K.J.; de Cabo, R.; Ungvari, Z. Anti-oxidative and anti-inflammatory vasoprotective effects of caloric restriction in aging: Role of circulating factors and SIRT1. Mech. Ageing Dev. 2009, 130, 518-527. [CrossRef] [PubMed]

35. Zanetti, M.; Gortan Cappellari, G.; Burekovic, I.; Barazzoni, R.; Stebel, M.; Guarnieri, G. Caloric restriction improves endothelial dysfunction during vascular aging: Effects on nitric oxide synthase isoforms and oxidative stress in rat aorta. Exp. Gerontol. 2010, 45, 848-855. [CrossRef] [PubMed]

36. Castello, L.; Froio, T.; Cavallini, G.; Biasi, F.; Sapino, A.; Leonarduzzi, G.; Bergamini, E.; Poli, G.; Chiarpotto, E. Calorie restriction protects against age-related rat aorta sclerosis. FASEB J. 2005, 19, 1863-1865. [CrossRef] [PubMed]

37. Ozbek, E.; Simsek, A.; Ozbek, M.; Somay, A. Caloric restriction increases internal iliac artery and penil nitric oxide synthase expression in rat: Comparison of aged and adult rats. Arch. Ital. Urol. Androl. 2013, 85, 113-117. [CrossRef] [PubMed]

38. Minamiyama, Y.; Bito, Y.; Takemura, S.; Takahashi, Y.; Kodai, S.; Mizuguchi, S.; Nishikawa, Y.; Suehiro, S.; Okada, S. Calorie restriction improves cardiovascular risk factors via reduction of mitochondrial reactive oxygen species in type II diabetic rats. J. Pharmacol. Exp. Ther. 2007, 320, 535-543. [CrossRef] [PubMed]

39. Garcia-Prieto, C.F.; Pulido-Olmo, H.; Ruiz-Hurtado, G.; Gil-Ortega, M.; Aranguez, I.; Rubio, M.A.; Ruiz-Gayo, M.; Somoza, B.; Fernandez-Alfonso, M.S. Mild caloric restriction reduces blood pressure and activates endothelial AMPK-PI3K-Akt-eNOS pathway in obese Zucker rats. Vascul. Pharmacol. 2015, 65-66, 3-12. [CrossRef] [PubMed]

40. Ketonen, J.; Pilvi, T.; Mervaala, E. Caloric restriction reverses high-fat diet-induced endothelial dysfunction and vascular superoxide production in C57Bl/6 mice. Heart Vessel. 2010, 25, 254-262. [CrossRef] [PubMed] 
41. Iacobellis, G.; Singh, N.; Wharton, S.; Sharma, A.M. Substantial changes in epicardial fat thickness after weight loss in severely obese subjects. Obesity (Silver Spring) 2008, 16, 1693-1697. [CrossRef] [PubMed]

42. Siklova-Vitkova, M.; Klimcakova, E.; Polak, J.; Kovacova, Z.; Tencerova, M.; Rossmeislova, L.; Bajzova, M.; Langin, D.; Stich, V. Adipose tissue secretion and expression of adipocyte-produced and stromavascular fraction-produced adipokines vary during multiple phases of weight-reducing dietary intervention in obese women. J. Clin. Endocrinol. Metab. 2012, 97, E1176-E1181. [CrossRef] [PubMed]

43. Capel, F.; Klimcakova, E.; Viguerie, N.; Roussel, B.; Vitkova, M.; Kovacikova, M.; Polak, J.; Kovacova, Z.; Galitzky, J.; Maoret, J.J.; et al. Macrophages and adipocytes in human obesity: Adipose tissue gene expression and insulin sensitivity during calorie restriction and weight stabilization. Diabetes 2009, 58, 1558-1567. [CrossRef] [PubMed]

44. Morel, O.; Luca, F.; Grunebaum, L.; Jesel, L.; Meyer, N.; Desprez, D.; Robert, S.; Dignat-George, F.; Toti, F.; Simon, C.; et al. Short-term very low-calorie diet in obese females improves the haemostatic balance through the reduction of leptin levels, PAI-1 concentrations and a diminished release of platelet and leukocyte-derived microparticles. Int. J. Obes. 2011, 35, 1479-1486. [CrossRef] [PubMed]

45. Murakami, T.; Horigome, H.; Tanaka, K.; Nakata, Y.; Ohkawara, K.; Katayama, Y.; Matsui, A. Impact of weight reduction on production of platelet-derived microparticles and fibrinolytic parameters in obesity. Thromb. Res. 2007, 119, 45-53. [CrossRef] [PubMed]

46. Robertson, L.T.; Mitchell, J.R. Benefits of short-term dietary restriction in mammals. Exp. Gerontol. 2013, 48, 1043-1048. [CrossRef] [PubMed]

47. Cartee, G.D.; Dean, D.J. Glucose transport with brief dietary restriction: Heterogenous responses in muscles. Am. J. Physiol. 1994, 266, E946-E952. [PubMed]

48. Mattagajasingh, I.; Kim, C.S.; Naqvi, A.; Yamamori, T.; Hoffman, T.A.; Jung, S.B.; DeRicco, J.; Kasuno, K.; Irani, K. SIRT1 promotes endothelium-dependent vascular relaxation by activating endothelial nitric oxide synthase. Proc. Natl. Acad. Sci. USA 2007, 104, 14855-14860. [CrossRef] [PubMed]

49. Weindruch, R.; Walford, R.L. Dietary restriction in mice beginning at 1 year of age: Effect on life-span and spontaneous cancer incidence. Science 1982, 215, 1415-1418. [CrossRef] [PubMed]

50. Weindruch, R.; Gottesman, S.R.; Walford, R.L. Modification of age-related immune decline in mice dietarily restricted from or after midadulthood. Proc. Natl. Acad. Sci. USA 1982, 79, 898-902. [CrossRef] [PubMed]

51. Forster, M.J.; Morris, P.; Sohal, R.S. Genotype and age influence the effect of caloric intake on mortality in mice. FASEB J. 2003, 17, 690-692. [CrossRef] [PubMed]

52. Arvidsson, E.; Viguerie, N.; Andersson, I.; Verdich, C.; Langin, D.; Arner, P. Effects of different hypocaloric diets on protein secretion from adipose tissue of obese women. Diabetes 2004, 53, 1966-1971. [CrossRef] [PubMed]

53. Fornieri, C.; Taparelli, F.; Quaglino, D.; Contri, M.B.; Davidson, J.M.; Algeri, S.; Ronchetti, I.P. The effect of caloric restriction on the aortic tissue of aging rats. Connect. Tissue Res. 1999, 40, 131-143. [CrossRef] [PubMed]

54. Zanetti, M.; Barazzoni, R.; Vadori, M.; Stebel, M.; Biolo, G.; Guarnieri, G. Lack of direct effect of moderate hyperleptinemia to improve endothelial function in lean rat aorta: Role of calorie restriction. Atherosclerosis 2004, 175, 253-259. [CrossRef] [PubMed]

55. Heilbronn, L.K.; Clifton, P.M. C-reactive protein and coronary artery disease: Influence of obesity, caloric restriction and weight loss. J. Nutr. Biochem. 2002, 13, 316-321. [CrossRef]

56. Garcia-Prieto, C.F.; Gil-Ortega, M.; Aranguez, I.; Ortiz-Besoain, M.; Somoza, B.; Fernandez-Alfonso, M.S. Vascular ampk as an attractive target in the treatment of vascular complications of obesity. Vascul. Pharmacol. 2015, 67-69, 10-20. [CrossRef] [PubMed]

57. García-Prieto, C.F.; Hernández-Nuño, F.; Rio, D.D.; Ruiz-Hurtado, G.; Aránguez, I.; Ruiz-Gayo, M.; Somoza, B.; Fernández-Alfonso, M.S. High-fat diet induces endothelial dysfunction through a down-regulation of the endothelial AMPK-PI3K-Akt-eNOS pathway. Mol. Nutr. Food Res. 2015, 59, 520-532. [CrossRef] [PubMed]

58. Lobato, N.S.; Filgueira, F.P.; Prakash, R.; Giachini, F.R.; Ergul, A.; Carvalho, M.H.; Webb, R.C.; Tostes, R.C.; Fortes, Z.B. Reduced endothelium-dependent relaxation to anandamide in mesenteric arteries from young obese Zucker rats. PLoS ONE 2013, 8, e63449. [CrossRef] [PubMed] 
59. Blume, C.; Benz, P.M.; Walter, U.; Ha, J.; Kemp, B.E.; Renné, T. Amp-activated protein kinase impairs endothelial actin cytoskeleton assembly by phosphorylating vasodilator-stimulated phosphoprotein. J. Biol. Chem. 2007, 282, 4601-4612. [CrossRef] [PubMed]

60. Lee, W.J.; Lee, I.K.; Kim, H.S.; Kim, Y.M.; Koh, E.H.; Won, J.C.; Han, S.M.; Kim, M.S.; Jo, I.; Oh, G.T.; et al. Alpha-lipoic acid prevents endothelial dysfunction in obese rats via activation of AMP-activated protein kinase. Arterioscler. Thromb. Vasc. Biol. 2005, 25, 2488-2494. [CrossRef] [PubMed]

61. Dagher, Z.; Ruderman, N.; Tornheim, K.; Ido, Y. Acute regulation of fatty acid oxidation and amp-activated protein kinase in human umbilical vein endothelial cells. Circ. Res. 2001, 88, 1276-1282. [CrossRef]

62. McCarty, M.F. Ampk activation as a strategy for reversing the endothelial lipotoxicity underlying the increased vascular risk associated with insulin resistance syndrome. Med. Hypotheses 2005, 64, 1211-1215. [CrossRef] [PubMed]

63. Allard, J.S.; Heilbronn, L.K.; Smith, C.; Hunt, N.D.; Ingram, D.K.; Ravussin, E.; de Cabo, R.; Team, P.C. In vitro cellular adaptations of indicators of longevity in response to treatment with serum collected from humans on calorie restricted diets. PLoS ONE 2008, 3, e3211. [CrossRef] [PubMed]

64. Briones, A.M.; Aras-Lopez, R.; Alonso, M.J.; Salaices, M. Small artery remodeling in obesity and insulin resistance. Curr. Vasc. Pharmacol. 2014, 12, 427-437. [CrossRef] [PubMed]

65. Walford, R.L.; Harris, S.B.; Gunion, M.W. The calorically restricted low-fat nutrient-dense diet in biosphere 2 significantly lowers blood glucose, total leukocyte count, cholesterol, and blood pressure in humans. Proc. Natl. Acad. Sci. USA 1992, 89, 11533-11537. [CrossRef] [PubMed]

66. Petersen, K.S.; Clifton, P.M.; Lister, N.; Keogh, J.B. Effect of weight loss induced by energy restriction on measures of arterial compliance: A systematic review and meta-analysis. Atherosclerosis 2016, 247, 7-20. [CrossRef] [PubMed]

67. Fernandez-Alfonso, M.S.; Gil-Ortega, M.; Garcia-Prieto, C.F.; Aranguez, I.; Ruiz-Gayo, M.; Somoza, B. Mechanisms of perivascular adipose tissue dysfunction in obesity. Int. J. Endocrinol. 2013, 2013, 402053. [CrossRef] [PubMed]

68. Iacobellis, G.; Ribaudo, M.C.; Assael, F.; Vecci, E.; Tiberti, C.; Zappaterreno, A.; di Mario, U.; Leonetti, F. Echocardiographic epicardial adipose tissue is related to anthropometric and clinical parameters of metabolic syndrome: A new indicator of cardiovascular risk. J. Clin. Endocrinol. Metab. 2003, 88, 5163-5168. [CrossRef] [PubMed]

69. Somoza, B.; Guzman, R.; Cano, V.; Merino, B.; Ramos, P.; Diez-Fernandez, C.; Fernandez-Alfonso, M.S.; Ruiz-Gayo, M. Induction of cardiac uncoupling protein-2 expression and adenosine 5 -monophosphate-activated protein kinase phosphorylation during early states of diet-induced obesity in mice. Endocrinology 2007, 148, 924-931. [CrossRef] [PubMed]

70. Gil-Ortega, M.; Condezo-Hoyos, L.; García-Prieto, C.F.; Arribas, S.M.; González, M.C.; Aranguez, I.; Ruiz-Gayo, M.; Somoza, B.; Fernández-Alfonso, M.S. Imbalance between pro and anti-oxidant mechanisms in perivascular adipose tissue aggravates long-term high-fat diet-derived endothelial dysfunction. PLOS ONE 2014, 9, e95312.

71. Greenstein, A.S.; Khavandi, K.; Withers, S.B.; Sonoyama, K.; Clancy, O.; Jeziorska, M.; Laing, I.; Yates, A.P.; Pemberton, P.W.; Malik, R.A.; et al. Local inflammation and hypoxia abolish the protective anticontractile properties of perivascular fat in obese patients. Circulation 2009, 119, 1661-1670. [CrossRef] [PubMed]

72. Ma, L.; Ma, S.; He, H.; Yang, D.; Chen, X.; Luo, Z.; Liu, D.; Zhu, Z. Perivascular fat-mediated vascular dysfunction and remodeling through the AMPK/mTOR pathway in high-fat diet-induced obese rats. Hypertens Res. 2010, 33, 446-453. [CrossRef] [PubMed]

73. Fésüs, G.; Dubrovska, G.; Gorzelniak, K.; Kluge, R.; Huang, Y.; Luft, F.C.; Gollasch, M. Adiponectin is a novel humoral vasodilator. Cardiovasc. Res. 2007, 75, 719-727. [CrossRef] [PubMed]

74. Owen, M.K.; Witzmann, F.A.; McKenney, M.L.; Lai, X.; Berwick, Z.C.; Moberly, S.P.; Alloosh, M.; Sturek, M.; Tune, J.D. Perivascular adipose tissue potentiates contraction of coronary vascular smooth muscle: Influence of obesity. Circulation 2013, 128, 9-18. [CrossRef] [PubMed]

75. Sun, X.; Hou, N.; Han, F.; Guo, Y.; Hui, Z.; Du, G.; Zhang, Y. Effect of high free fatty acids on the anti-contractile response of perivascular adipose tissue in rat aorta. J. Mol. Cell. Cardiol. 2013, 63, 169-174. [CrossRef] [PubMed] 
76. Rebolledo, A.; Rebolledo, O.R.; Marra, C.A.; Garcia, M.E.; Roldan Palomo, A.R.; Rimorini, L.; Gagliardino, J.J. Early alterations in vascular contractility associated to changes in fatty acid composition and oxidative stress markers in perivascular adipose tissue. Cardiovasc. Diabetol. 2010, 9, 65. [CrossRef] [PubMed]

77. Verlohren, S.; Dubrovska, G.; Tsang, S.Y.; Essin, K.; Luft, F.C.; Huang, Y.; Gollasch, M. Visceral periadventitial adipose tissue regulates arterial tone of mesenteric arteries. Hypertension 2004, 44, 271-276. [CrossRef] [PubMed]

78. Gálvez, B.; de Castro, J.; Herold, D.; Dubrovska, G.; Arribas, S.; González, M.C.; Aranguez, I.; Luft, F.C.; Ramos, M.P.; Gollasch, M.; et al. Perivascular adipose tissue and mesenteric vascular function in spontaneously hypertensive rats. Arterioscler. Thromb. Vasc. Biol. 2006, 26, 1297-1302. [CrossRef] [PubMed]

79. Willens, H.J.; Byers, P.; Chirinos, J.A.; Labrador, E.; Hare, J.M.; de Marchena, E. Effects of weight loss after bariatric surgery on epicardial fat measured using echocardiography. Am. J. Cardiol. 2007, 99, 1242-1245. [CrossRef] [PubMed]

80. Aghamohammadzadeh, R.; Greenstein, A.S.; Yadav, R.; Jeziorska, M.; Hama, S.; Soltani, F.; Pemberton, P.W.; Ammori, B.; Malik, R.A.; Soran, H.; et al. Effects of bariatric surgery on human small artery function: Evidence for reduction in perivascular adipocyte inflammation, and the restoration of normal anticontractile activity despite persistent obesity. J. Am. Coll. Cardiol. 2013, 62, 128-135. [CrossRef] [PubMed]

81. Rahmouni, K.; Correia, M.L.; Haynes, W.G.; Mark, A.L. Obesity-associated hypertension: New insights into mechanisms. Hypertension 2005, 45, 9-14. [CrossRef] [PubMed]

82. Blanquicett, C.; Graves, A.; Kleinhenz, D.J.; Hart, C.M. Attenuation of signaling and nitric oxide production following prolonged leptin exposure in human aortic endothelial cells. J. Investig. Med. 2007, 55, 368-377. [CrossRef] [PubMed]

83. Knudson, J.D.; Dincer, U.D.; Zhang, C.; Swafford, A.N., Jr.; Koshida, R.; Picchi, A.; Focardi, M.; Dick, G.M.; Tune, J.D. Leptin receptors are expressed in coronary arteries, and hyperleptinemia causes significant coronary endothelial dysfunction. Am. J. Physiol. Heart Circ. Physiol. 2005, 289, H48-H56. [CrossRef] [PubMed]

84. Bouloumie, A.; Marumo, T.; Lafontan, M.; Busse, R. Leptin induces oxidative stress in human endothelial cells. FASEB J. 1999, 13, 1231-1238. [PubMed]

85. Shinmura, K.; Tamaki, K.; Bolli, R. Short-term caloric restriction improves ischemic tolerance independent of opening of ATP-sensitive $\mathrm{K}^{+}$channels in both young and aged hearts. J. Mol. Cell. Cardiol. 2005, 39, 285-296. [CrossRef] [PubMed]

86. Zhu, M.; Miura, J.; Lu, L.X.; Bernier, M.; DeCabo, R.; Lane, M.A.; Roth, G.S.; Ingram, D.K. Circulating adiponectin levels increase in rats on caloric restriction: The potential for insulin sensitization. Exp. Gerontol. 2004, 39, 1049-1059. [CrossRef] [PubMed]

87. Gil-Ortega, M.; Stucchi, P.; Guzmán-Ruiz, R.; Cano, V.; Arribas, S.; González, M.C.; Ruiz-Gayo, M.; Fernández-Alfonso, M.S.; Somoza, B. Adaptative nitric oxide overproduction in perivascular adipose tissue during early diet-induced obesity. Endocrinology 2010, 151, 3299-3306. [CrossRef] [PubMed]

88. Antonopoulos, A.S.; Margaritis, M.; Coutinho, P.; Shirodaria, C.; Psarros, C.; Herdman, L.; Sanna, F.; De Silva, R.; Petrou, M.; Sayeed, R.; et al. Adiponectin as a link between type 2 diabetes and vascular NADPH oxidase activity in the human arterial wall: The regulatory role of perivascular adipose tissue. Diabetes 2015, 64, 2207-2219. [CrossRef] [PubMed]

89. Lavi, T.; Karasik, A.; Koren-Morag, N.; Kanety, H.; Feinberg, M.S.; Shechter, M. The acute effect of various glycemic index dietary carbohydrates on endothelial function in nondiabetic overweight and obese subjects. J. Am. Coll. Cardiol. 2009, 53, 2283-2287. [CrossRef] [PubMed]

90. Gögebakan, O.; Kohl, A.; Osterhoff, M.A.; van Baak, M.A.; Jebb, S.A.; Papadaki, A.; Martinez, J.A.; Handjieva-Darlenska, T.; Hlavaty, P.; Weickert, M.O.; et al. Effects of weight loss and long-term weight maintenance with diets varying in protein and glycemic index on cardiovascular risk factors: The diet, obesity, and genes (diogenes) study: A randomized, controlled trial. Circulation 2011, 124, 2829-2838. [CrossRef] [PubMed]

91. Buscemi, S.; Cosentino, L.; Rosafio, G.; Morgana, M.; Mattina, A.; Sprini, D.; Verga, S.; Rini, G.B. Effects of hypocaloric diets with different glycemic indexes on endothelial function and glycemic variability in overweight and in obese adult patients at increased cardiovascular risk. Clin. Nutr. 2013, 32, 346-352. [CrossRef] [PubMed] 
92. Volek, J.S.; Fernandez, M.L.; Feinman, R.D.; Phinney, S.D. Dietary carbohydrate restriction induces a unique metabolic state positively affecting atherogenic dyslipidemia, fatty acid partitioning, and metabolic syndrome. Prog. Lipid Res. 2008, 47, 307-318. [CrossRef] [PubMed]

93. Volek, J.S.; Phinney, S.D.; Forsythe, C.E.; Quann, E.E.; Wood, R.J.; Puglisi, M.J.; Kraemer, W.J.; Bibus, D.M.; Fernandez, M.L.; Feinman, R.D. Carbohydrate restriction has a more favorable impact on the metabolic syndrome than a low fat diet. Lipids 2009, 44, 297-309. [CrossRef] [PubMed]

94. Volek, J.S.; Ballard, K.D.; Silvestre, R.; Judelson, D.A.; Quann, E.E.; Forsythe, C.E.; Fernandez, M.L.; Kraemer, W.J. Effects of dietary carbohydrate restriction versus low-fat diet on flow-mediated dilation. Metabolism 2009, 58, 1769-1777. [CrossRef] [PubMed]

95. Forsythe, C.E.; Phinney, S.D.; Fernandez, M.L.; Quann, E.E.; Wood, R.J.; Bibus, D.M.; Kraemer, W.J.; Feinman, R.D.; Volek, J.S. Comparison of low fat and low carbohydrate diets on circulating fatty acid composition and markers of inflammation. Lipids 2008, 43, 65-77. [CrossRef] [PubMed]

96. Clifton, P.M.; Keogh, J.B.; Foster, P.R.; Noakes, M. Effect of weight loss on inflammatory and endothelial markers and fmd using two low-fat diets. Int. J. Obes. 2005, 29, 1445-1451. [CrossRef] [PubMed]

97. Wycherley, T.P.; Brinkworth, G.D.; Keogh, J.B.; Noakes, M.; Buckley, J.D.; Clifton, P.M. Long-term effects of weight loss with a very low carbohydrate and low fat diet on vascular function in overweight and obese patients. J. Intern. Med. 2010, 267, 452-461. [CrossRef] [PubMed]

98. Ballard, K.D.; Quann, E.E.; Kupchak, B.R.; Volk, B.M.; Kawiecki, D.M.; Fernandez, M.L.; Seip, R.L.; Maresh, C.M.; Kraemer, W.J.; Volek, J.S. Dietary carbohydrate restriction improves insulin sensitivity, blood pressure, microvascular function, and cellular adhesion markers in individuals taking statins. Nutr. Res. 2013, 33, 905-912. [CrossRef] [PubMed]

99. Alessi, M.C.; Juhan-Vague, I. PAI-1 and the metabolic syndrome: Links, causes, and consequences. Arterioscler. Thromb. Vasc. Biol. 2006, 26, 2200-2207. [CrossRef] [PubMed]

100. Tagawa, T.; Imaizumi, T.; Endo, T.; Shiramoto, M.; Harasawa, Y.; Takeshita, A. Role of nitric oxide in reactive hyperemia in human forearm vessels. Circulation 1994, 90, 2285-2290. [CrossRef] [PubMed]

101. Merino, J.; Kones, R.; Ferré, R.; Plana, N.; Girona, J.; Aragonés, G.; Ibarretxe, D.; Heras, M.; Masana, L. Negative effect of a low-carbohydrate, high-protein, high-fat diet on small peripheral artery reactivity in patients with increased cardiovascular risk. Br. J. Nutr. 2013, 109, 1241-1247. [CrossRef] [PubMed]

102. Hite, A.H.; Berkowitz, V.G.; Berkowitz, K. Low-carbohydrate diet review: Shifting the paradigm. Nutr. Clin. Pract. 2011, 26, 300-308. [CrossRef] [PubMed]

103. Larsen, T.M.; Dalskov, S.M.; van Baak, M.; Jebb, S.A.; Papadaki, A.; Pfeiffer, A.F.; Martinez, J.A.; Handjieva-Darlenska, T.; Kunešová, M.; Pihlsgård, M.; et al. Diets with high or low protein content and glycemic index for weight-loss maintenance. N. Engl. J. Med. 2010, 363, 2102-2113. [CrossRef] [PubMed]

104. Brinkworth, G.D.; Noakes, M.; Parker, B.; Foster, P.; Clifton, P.M. Long-term effects of advice to consume a high-protein, low-fat diet, rather than a conventional weight-loss diet, in obese adults with type 2 diabetes: One-year follow-up of a randomised trial. Diabetologia 2004, 47, 1677-1686. [CrossRef] [PubMed]

105. Khoo, J.; Ling, P.S.; Tan, J.; Teo, A.; Ng, H.L.; Chen, R.Y.; Tay, T.L.; Tan, E.; Cheong, M. Comparing the effects of meal replacements with reduced-fat diet on weight, sexual and endothelial function, testosterone and quality of life in obese asian men. Int. J. Impot. Res. 2014, 26, 61-66. [CrossRef] [PubMed]

106. Rizkalla, S.W.; Prifti, E.; Cotillard, A.; Pelloux, V.; Rouault, C.; Allouche, R.; Laromiguière, M.; Kong, L.; Darakhshan, F.; Massiera, F.; et al. Differential effects of macronutrient content in 2 energy-restricted diets on cardiovascular risk factors and adipose tissue cell size in moderately obese individuals: A randomized controlled trial. Am. J. Clin. Nutr. 2012, 95, 49-63. [CrossRef] [PubMed]

107. Ridker, P.M. High-sensitivity C-reactive protein: Potential adjunct for global risk assessment in the primary prevention of cardiovascular disease. Circulation 2001, 103, 1813-1818. [CrossRef] [PubMed]

108. Appel, L.J.; Sacks, F.M.; Carey, V.J.; Obarzanek, E.; Swain, J.F.; Miller, E.R.; Conlin, P.R.; Erlinger, T.P.; Rosner, B.A.; Laranjo, N.M.; et al. Effects of protein, monounsaturated fat, and carbohydrate intake on blood pressure and serum lipids: Results of the omniheart randomized trial. JAMA 2005, 294, 2455-2464. [CrossRef] [PubMed]

109. Bonetti, P.O.; Pumper, G.M.; Higano, S.T.; Holmes, D.R.; Kuvin, J.T.; Lerman, A. Noninvasive identification of patients with early coronary atherosclerosis by assessment of digital reactive hyperemia. J. Am. Coll. Cardiol. 2004, 44, 2137-2141. [CrossRef] [PubMed] 
110. Rubinshtein, R.; Kuvin, J.T.; Soffler, M.; Lennon, R.J.; Lavi, S.; Nelson, R.E.; Pumper, G.M.; Lerman, L.O.; Lerman, A. Assessment of endothelial function by non-invasive peripheral arterial tonometry predicts late cardiovascular adverse events. Eur. Heart J. 2010, 31, 1142-1148. [CrossRef] [PubMed]

111. Siri-Tarino, P.W.; Sun, Q.; Hu, F.B.; Krauss, R.M. Saturated fat, carbohydrate, and cardiovascular disease. Am. J. Clin. Nutr. 2010, 91, 502-509. [CrossRef] [PubMed]

112. Lagiou, P.; Sandin, S.; Lof, M.; Trichopoulos, D.; Adami, H.O.; Weiderpass, E. Low carbohydrate-high protein diet and incidence of cardiovascular diseases in swedish women: Prospective cohort study. BMJ 2012, 344, e4026. [CrossRef] [PubMed]

113. Noto, H.; Goto, A.; Tsujimoto, T.; Noda, M. Low-carbohydrate diets and all-cause mortality: A systematic review and meta-analysis of observational studies. PLOS ONE 2013, 8, e55030. [CrossRef] [PubMed]

114. Jenkins, D.J.; Wolever, T.M.; Taylor, R.H.; Barker, H.; Fielden, H.; Baldwin, J.M.; Bowling, A.C.; Newman, H.C.; Jenkins, A.L.; Goff, D.V. Glycemic index of foods: A physiological basis for carbohydrate exchange. Am. J. Clin. Nutr. 1981, 34, 362-366. [PubMed]

115. McMillan-Price, J.; Petocz, P.; Atkinson, F.; O'neill, K.; Samman, S.; Steinbeck, K.; Caterson, I.; Brand-Miller, J. Comparison of 4 diets of varying glycemic load on weight loss and cardiovascular risk reduction in overweight and obese young adults: A randomized controlled trial. Arch. Intern. Med. 2006, 166, 1466-1475. [CrossRef] [PubMed]

116. Recio-Rodriguez, J.I.; Gomez-Marcos, M.A.; Patino-Alonso, M.C.; Rodrigo-De Pablo, E.; Cabrejas-Sánchez, A.; Arietaleanizbeaskoa, M.S.; Repiso-Gento, I.; Gonzalez-Viejo, N.; Maderuelo-Fernandez, J.A.; Agudo-Conde, C.; et al. Glycemic index, glycemic load, and pulse wave reflection in adults. Nutr. Metab. Cardiovasc. Dis. 2015, 25, 68-74. [CrossRef] [PubMed]

117. Hu, Y.; Block, G.; Norkus, E.P.; Morrow, J.D.; Dietrich, M.; Hudes, M. Relations of glycemic index and glycemic load with plasma oxidative stress markers. Am. J. Clin. Nutr. 2006, 84, 70-76, quiz 266-267. [PubMed]

118. Sacks, F.M.; Carey, V.J.; Anderson, C.A.; Miller, E.R.; Copeland, T.; Charleston, J.; Harshfield, B.J.; Laranjo, N.; McCarron, P.; Swain, J.; et al. Effects of high vs low glycemic index of dietary carbohydrate on cardiovascular disease risk factors and insulin sensitivity: The omnicarb randomized clinical trial. JAMA 2014, 312, 2531-2541. [CrossRef] [PubMed]

119. Schwingshackl, L.; Hoffmann, G. Long-term effects of low glycemic index/load vs. High glycemic index/load diets on parameters of obesity and obesity-associated risks: A systematic review and meta-analysis. Nutr. Metab. Cardiovasc. Dis. 2013, 23, 699-706. [CrossRef]

(C) 2016 by the authors; licensee MDPI, Basel, Switzerland. This article is an open access article distributed under the terms and conditions of the Creative Commons Attribution (CC-BY) license (http://creativecommons.org/licenses/by/4.0/). 